\title{
Mutual Legal Assistance pada Pemberantasan Cyber Crime Lintas Yurisdiksi di Indonesia
}

\author{
Bambang Hartono ${ }^{1}$ \\ Recca Ayu Hapsari ${ }^{2}$ \\ ${ }^{1}$ Fakultas Hukum Universitas Bandar Lampung, Bandar Lampung, Indonesia \\ E-mail: bambang.hartono@ubl.ac.id \\ ${ }^{2}$ Fakultas Hukum Universitas Bandar Lampung, Bandar Lampung, Indonesia \\ E-mail: recca@ubl.ac.id
}

\begin{abstract}
The development of global information and transportation technology is accompanied by the development of criminal acts that no longer recognize jurisdictional boundaries, so that the response requires joint handling of world countries. Mutual assistance in criminal matters is one way to stop fraudulent acts of criminals who want to hide assets. The implementation of the Mutual Legal Assistance System was realized in the implementation of Law Number 1 of 2006 concerning Reciprocal Assistance in Criminal Issues, namely by establishing cooperation with countries that have the potential to be used as hiding places or to save income from the crime. This has become one of the efforts to prevent cross-jurisdictional cyber crime by implementing a Mutual Legal Assistance System
\end{abstract}

Keywords: Mutual Legal Assistance, Cyber Crime, Cross Jurisdiction, Indonesia.

\section{A. PENDAHULUAN.}

Bagi perekonomian, kemajuan teknologi memberikan manfaat yang sangat besar, karena transaksi bisnis dapat dilakukan secara seketika (real time), yang berarti perputaran ekonomi menjadi semakin cepat dan dapat dilakukan tanpa hambatan ruang dan waktu, begitu juga dari sisi keamanan, penggunaan teknologi memberikan perlindungan terhadap keamnanan data dan teransaksi. Namun disisi lain, perkembangan teknologi yang begitu cepat tidak dapat dipungkiri telah menimbulkan ekses negatif, yaitu berkembangnya kejahatan yang lebih canggih yang dikenal sebagai cybercrime, bahkan lebih jauh lagi adalah dimanfaatkannya kecanggihan teknologi informasi dan komputer oleh pelaku kejahatan untuk tujuan pencucian uang dan kejahatan terorisme.

Kemajuan ilmu pengetahuan dan teknologi, di samping mempunyai dampak positif bagi kehidupan manusia juga membawa dampak negatif yang dapat 
merugikan orang perorangan, masyarakat, dan/atau negara. Salah satu dampak negatif kemajuan ilmu pengetahuan dan teknologi yaitu disalahgunakannya kemajuan ilmu pengetahuan dan teknologi ini oleh sebagian orang tertentu sebagai media untuk melakukan kejahatan, khususnya kejahatan yang dilakukan melalui dunia maya (cyber crime).

Penggunaan komputer dan internet sebagai sarana informasi telah menjadi kebutuhan masyarakat untuk melakukan berbagai aktifitas dalam pergaulan hidup di masyarakat, teknologi ini sering dikatakan oleh sebagian orang sebagai media tanpa batas. Perkembangan internet yang cukup pesat dan semakin canggih ini telah memberikan berbagai kemudahan bagi setiap orang, bukan saja sekedar untuk berkomunikasi tapi juga melakukan transaksi bisnis kapan saja dan di mana saja, juga dalam hal melakukan perbuatan tertentu tanpa harus berada di suatu wilayah tertentu ataupun dalam suatu negara tertentu, sehingga segala sesuatu dapat dilakukan dengan mudah, tanpa dibatasi waktu dan/atau tempat.

Kemunculan internet dapat dikatakan merupakan hasil dari revolusi informasi yang sangat mengagumkan, membanggakan oleh karena secara mendasar mengandung ciri praktis dan memudahkan, baik untuk penggunaan secara orang perorangan maupun organisasi atau institusional, dalam berbagai aspek kehidupan. Ciri tersebut tidak terlepas dari kekuatan dan kecepatan internet dalam tatanan operasionalnya yang antara lain dapat menembus ruang dan waktu. Dengan ciri dan sifat internet yang demikian itu, maka patut dicermati bahwa penyalahgunaan internet membawa dampak munculnya jenis kejahatan baru yakni cyber crime.

Seiring dengan perkembangan zaman, maka perkembangan jenis kejahatan internasional ikut bertambah.

1 Atmasasmita, Romli. (2000). Pengantar Hukum Pidana Internasional. Bandung: Refika Aditama, h. 42.
Bassiouni menyebutkan dalam bukunya terdapat 22 (dua puluh dua jenis) kejahatan yang dapat dikategorikan sebagai kejahatan internasional. Akan tetapi dalam beberapa dekade terakhir, setidaknya-tidaknya ada dua jenis kejahatan baru yang kemudianjuga turut dikategorikadikategorikan sebagai bentuk kejahatan transnasional yang sangat perlu untuk diperhatikan oleh negaranegara di dunia. Kejahatan-kejahatan tersebut antara lain korupsi (coruption), terorisme dan kejahatan virtual atau yang biasa disebut dengan cyber crime. ${ }^{1}$

Cyber crime yang menggunakan media komunikasi dan komputer, kendati berada di dunia lain dalam bentuk maya tetapi memliki dampak yang sangat nyata. Penyimpangan dan kerugian besar telah terjadi dan dirasakan oleh masyarakat di berbagai penjuru dunia. Kerugian berdampak luas kepada sektor-sektor lain di bidang ekonomi, perbankan, moneter dan sektor lain yang menggunakan jaringan komputer. $^{2}$

Cyber crime merupakan suatu tindak pidana yang bersifat transnasional atau lintas negara mengakibatkan timbulnya permasalahan hukum suatu negara dengan negara lain yang memerlukan penanganan melalui hubungan baik berdasarkan hukum di masing-masing negara, dimana penanganan tindak pidana transnasional harus dilakukan dengan bekerja sama antarnegara dalam bentuk bantuan timbal balik dalam masalah pidana.

Kejahatan cyber tidak mengenal batas wilayah (borderless) serta waktu kejadian karena korban dan pelaku sering berada di negara yang berbeda. Semua aksi itu dapat dilakukan hanya dari depan komputer yang memiliki akses Internet tanpa takut diketahui oleh orang lain/saksi mata, sehingga kejahatan ini termasuk dalam Transnational Crime/kejahatan antar negara yang pengungkapannya sering melibatkan penegak hukum lebih

2 Sutarman. (2007). Cyber Crime-Modus Operandi dan Penanggulangannya. Jogjakarta: Laksbang Pressindo, h. 5. 
dari satu negara.

Cyber Crime sekarang ini telah berkembang menjadi tindak pidana yang bersifat transnasional, tindak pidana yang tidak mengenal batas yurisdiksi, dalam upaya meloloskan diri dari tuntutan hukum atas tindak pidana yang telah dilakukan. Tindakan tersebut jelas dapat mempersulit upaya penyidikan, penuntutan, dan pemeriksaan di sidang pengadilan atau bahkan untuk pelaksanaan putusan pengadilan. Tindak pidana ini bahkan mengakibatkan timbulnya permasalahan hukum suatu negara dengan negara lain sehingga upaya penanggulangan dan pemberantasannya sulit dilakukan tanpa kerja sama dan harmonisasi kebijakan dengan negara lain. Oleh karena itu untuk menanggulangi dan memberantasnya memerlukan hubungan baik dan kerja sama antar Negara dalam masalah pidana, guna saling memberikan bantuan dalam rangka penanggulangan dan pemberantasan tindak pidana dalam kasus-kasus cybercrime yang bersifat transnasional berdasarkan hukum masingmasing negara

Menurut Sutan Remy Syahdeini mengatakan bahwa instrumen internasional yang berkaitan dengan cyber crime adalah Convention on Cyber Crime tanggal 23 November 2001 di kota Budapest. Konvensi ini dibentuk untuk memperoleh kesatuan kebijakan pidana (criminal policy), meredam penyalahgunaan system, jaringan dan data computer agar masyarakat terlindung dari cyber crime, terutama dengan mengadopsi peraturan perundang-undangan yang memadai dan memperkuat kerjasama internasional. ${ }^{3}$

Saat ini, Pemerintah Indonesia telah memiliki Undang-Undang Nomor 1 Tahun 1979 tentang Ekstradisi untuk tujuan penyerahan orang (pelaku kejahatan) dan Undang-Undang Nomor 1 Tahun 2006 tentang Bantuan Timbal Balik dalam Masalah Pidana. Undang-undang tersebut sebagai pedoman bagi Pemerintah Republik Indonesia dalam meminta dan/atau memberikan bantuan timbal balik dan membuat perjanjian dengan negara asing dan sedapat mungkin membantu penegakan hukum di negara lain sepanjang tidak bertentangan dengan kepentingan dan hukum di Negara Indonesia. Bantuan timbal balik menjadi landasan hukum bagi para pihak untuk memberikan bantuan timbal balik berkenaan dengan penyidikan, penuntutan, dan pemeriksaan di sidang pengadilan sesuai dengan ketentuan peraturan perundang-undangan Negara Peminta. Berkaitan dengan hal tersebut, Indonesia telah melakukan kerjasama dengan beberapa negara, terutama negaranegara yang sering dijadikan tempat pelarian. Ektradisi dan Bantuan Timbal Balik, keduanya harus saling melengkapi dan tidak dilihat secara terpisah.

Sistem Bantuan Timbal Balik dalam Masalah Pidana (Mutual Legal Assistance) atau sering disingkat dengan MLA merupakan sistem kerjasama internasional dalam bidang pencegahan dan pemberantasan kejahatan khususnya terhadap kejahatan lintas negara (transnational crime). Sistem ini lahir dari kaidah-kaidah hubungan antar negara yang telah diterapkan oleh Indonesia baik dengan perjanjian maupun tidak. Perkembangan ilmu pengetahuan dan teknologi yang cukup pesat dan semakin canggih dewasa ini khususnya baik di bidang transportasi, komunikasi, maupun informasi serta dengan semakin meningkatnya arus globalisasi telah menyebabkan wilayah Negara yang satu dengan wilayah negara yang lain seakanakan tanpa batas sehingga perpindahan orang atau barang dari satu negara ke negara lain dilakukan dengan mudah dan cepat.

Berdasarkan uraian tersebut di atas,

3 Syahdeini, Sutan Remy. (2009). Kejahatan \& Tindak Pidana Komputer. Jakarta: Pustaka Utama Grafiti, h. 222. 
maka yang menjadi permasalahan yang akan dikaji dalam penulisan ini adalah : bagaimanakah penerapan Sistem Bantuan Timbal Balik dalam Masalah Pidana (Mutual Legal Assistance) atau sering disingkat dengan MLA dilaksanakan?, serta bagaimana kaitan antara Sistem Bantuan Timbal Balik dalam Masalah Pidana (Mutual Legal Assistance) atau sering disingkat dengan MLA dalam pemberantasan Cyber Crime Lintas Yurisdiksi”

\section{B. METODE PENELITIAN}

Penelitian ini menggunakan 2 (dua) pendekatan masalah, yaitu pendekatan yuridis normatif dan pendekatan empiris, dengan rincian sebagai berikut. Pendekatan yuridis normatif adalah suatu pendekatan yang dilakukan dengan cara studi kepustakaan (library research) dengan mengkaji, mempelajari dan menelaah teori, pandangan, konsep, serta peraturan perundang-undangan yang berkaitan dengan permasalahan yang ada di dalam penelitian ini. Sedangkan pendekatan empiris yaitu pendekatan yang dilakukan dengan mengadakan penelitian di lapangan sebagai objek penelitian dengan cara observasi dan wawancara guna memperoleh gambaran dan data yang berkaitan dengan permasalahan.

Analisis data dimaksudkan untuk menyederhanakan ke dalam bentuk yang mudah dibaca dan dipahami untuk diinterpretasikan. Metode analisis yang dipergunakan dalam penulisan ini adalah dengan analisis data secara kualitatif yaitu dengan menguraikan data secara sistematis guna memperoleh pengertian dan kesimpulan tertentu dalam hubungannya menjawab permasalahan, kemudian ditarik kesimpulan secara induktif, yaitu cara berfikir untuk mengambil kesimpulan yang bersifat umum guna menjawab permasalahan yang telah dikemukakan dengan didasarkan pada fakta-fakta yang bersifat khusus

\section{PEMBAHASAN}

\section{Penerapan Sistem Bantuan Timbal Balik dalam Masalah Pidana (Mutual Legal Assistance) atau sering disingkat dengan MLA}

Mempersiapkan penanggulangan dan pemberantasan timbulnya tindak pidana memerlukan kerja sama antar negara yang efektif bersifat bilateral, dalam hal ini dalam bentuk bantuan timbal balik dalam masalah pidana kemudian disebut bantuan yang merupakan permintaan bantuan berkenaan dengan penyidikan, penuntutan, dan pemeriksaan di sidang pengadilan sesuai dengan ketentuan peraturan perundang- undangan Negara Republik Indonesia.

Perkembangan kejahatan yang mengancam terwujudnya ketertiban dan perdamaian yang tidak lagi mengenal batas yurisdiksi suatu negara. Oleh karena itu, dalam upaya penanggulangannya memerlukan kerja sama antarnegara, baik melalui perjanjian bilateral maupun multilateral atau melalui hubungan baik berdasarkan hukum nasional negara masing-masing dengan tetap mepertimbangkan kaidah hukum internasional.

Pembentukan perjanjian bantuan timbal balik dalam masalah pidana dilatarbelakangi adanya perbedaan sistem hukum dan sistem peradilan pidana di antara beberapa negara yang dapat menghambat proses penyelesaian kejahatan karena setiap negara ingin menerapkan sistem hukum negaranya masing-masing. Hal ini mengakibatkan penanganan terhadap kejahatan menjadi lamban dan berbelit-belit. Selain itu, kendala diplomatik juga menjadi faktor yang sangat signifikan bagi terhambatnya penanganan kejahatan, karena kondisi ini menyangkut kedaulatan suatu negara yang harus senantiasa dihormati

Kerja sama internasional melalui mekanisme bantuan timbal balik dalam masalah pidana menunjukkan 
perkembangan yang semakin meningkat sejalan dengan meningkatnya upaya masyarakat internasional dalam pencegahan dan pemberantasan kejahatan lintas negara. Kerja sama tersebut memerlukan landasan hukum yang lebih kokoh serta selaras dengan kebutuhan hukum masyarakat. Untuk memberikan dasar hukum yang kuat mengenai kerja sama antara Pemerintah Republik Indonesia dengan negara lain dalam bentuk bantuan timbal balik dalam masalah pidana diperlukan perangkat hukum yang dapat dijadikan pedoman bagi Pemerintah Republik Indonesia. Pada tahun 2006, Indonesia telah mengesahkan Undang-Undang Nomor 1 Timbal Balik) sebagai landasan bagi Pemerintah Republik Indonesia dalam meminta kepada dan/atau menerima permintaan bantuan dari negara asing.tahun 2006 tentang Bantuan Timbal Balik dalam Masalah Pidana ${ }^{4}$.

Berdasarkan Pasal 5 UndangUndang Nomor 1 Tahun 2006 tentang Bantuan Timbal Balik dalam Masalah Pidana, yang menyebutkan bahwa bantuan timbal balik dalam masalah pidana dapat dilakukan dengan dasar perjanjian. Namun, jika belum ada perjanjian maka dapat dimungkinkan bantuan timbal balik tersebut dilakukan berdasarkan hubungan baik dengan asas resiprositas.

Indonesia sendiri telah meratifikasi perjanjian tersebut melalui Undangundang Nomor 15 Tahun 2008 Tentang Pengesahan Treaty on Mutual Legal Assistance in Criminal Matters. Di antara negara-negara ASEAN tinggal Kamboja, Filipina dan Thailand yang sudah menandatangani namun belum meratifikasinya. Perjanjian tersebut mewajibkan para Pihak untuk memberlakukan upaya-upaya MLA seluas apapun antara satu sama lain, dan terkait

${ }^{4}$ Latifah, Marfuatul. (2016). Penunjukan Otoritas Pusat Dalam Bantuan Timbal Balik Pidana Di Indonesia. Jurnal Negara Hukum: Vol. 7, No. 1, Juni 2016. h.51-69

${ }^{5}$ Direktorat Perjanjian Internasional Politik pada legislasi nasional Negara Diminta. Perjanjian ini mencakup berbagai jenis MLA yang biasa dapat ditemukan di dalam perjanjian-perjanjian bilateral, misalnya hal-hal terkait pengambilan bukti, pencarian dan penyitaan aset.

Adapun Indonesia memiliki perjanjian bantuan timbal-balik dengan negara-negara sebagai berikut:

1) Australia, 27 Oktober 1995, diratifikasi dengan UU No. 1 Tahun 1999;

2) China, 24 Juli 2000, diratifikasi dengan UU No. 8 Tahun 2006;

3) Korea Selatan, 30 Maret 2002 (masih dalam proses ratifikasi)

4) Hong Kong SAR, 3 April 2008 (masih dalam proses ratifikasi)

5) India, 25 Januari 2011 (masih dalam proses ratifikasi).

Mekanisme dalam lingkup ASEAN yang dapat dilakukan untuk pengembalian harta yang mungkin dilarikan ke yurisdiksi Singapura adalah melalui ASEAN Like-Minded Countries Mutual Legal Assistance Treaty yang telah ditandatangani dan berlaku di negaranegara Asia Tenggara, sebagai berikut Negara Penandatangan dan tanggal berlaku:

1) Brunei Darussalam 29 November 2004 berlaku 15 Februari 2006

2) Indonesia 29 November 2004 berlaku 4 Juni 2008

3) Laos 29 November 2004 berlaku 20 Juni 2007

4) Malaysia 29 November 2004 berlaku 1 Juni 2005

5) Singapura 20 November 2004 berlaku 28 April 2005

6) Vietnam 29 November 2004 berlaku 25 Oktober $2005^{5}$

Berdasarkan data Kementerian Luar

dan Keamanan Wilayah Kementerian Luar Negeri Republik Indonesia. (2010). Pointers Upaya Pemerintah RI dalam Pengembalian Aset (Asset Recovery) Hasil Tindak Pidana di Luar Negeri. 
Negeri RI, DirektoratJenderal dan Konsuler, penandatanganan nota kesepahaman dilakukan negara Republik Indonesia usai pertemuan Presiden Jokowi dengan Presiden Iran Hassan Rouhani di Istana Sa'dabad, Teheran. Ada 4 (empat) nota kesepakatan yang ditandatangani yakni Mutual Legal Assistance (MLA), ekstradisi, kelistrikan dan energi, serta investasi. Perkembangan hubungan diplomatik antara Republik Indonesia dan Republik Islam Iran selain meningkatkan hubungan persahabatan dan hubungan dagang, juga meningkatnya ilmu pengetahuan dan teknologi khususnya di bidang transportasi, komunikasi, dan informasi. Selain hubungan tersebut mempunyai dampak positif tetapi tidak menutup kemungkinan adanya dampak negatip, yaitu timbulnya tindak pidana yang tidak lagi mengenal batas yurisdiksi suatu Negara, sehingga penanggulangan dan pemberantasannya memerlukan kerja sama antar negara yang efektif bersifat bilateral. Guna perjanjian MLA, Indonesia telah memiliki perjanjian MLA bilateral dengan Australia, Korea Selatan, Hongkong, RRT, Vietnam, dan UEA.Lebih lanjut, bahwa perjanjianperjanjian MLA yang telah diratifikasi Indonesia tersebut menunjukkan komitmen kuat Republik Indonesia untuk mecegah dan memberantas kejahatan lintas negara ${ }^{6}$.

Kerja sama internasional bertujuan mencegah dan memberantas kejahatan. Dalam hal ini, dikenal beberapa kerja sama internasional, yaitu bantuan timbal balik dalam masalah pidana, ekstradisi, pemindahan narapidana, dan pemindahan proses hukum (transfer of proceeding). Bantuan timbal balik dalam masalah pidana sebagaimana diatur dalam ketentuan internasional seperti United Nations Convention against Corruption (UNCAC) dan United Nations

${ }^{6}$ Kementerian Luar Negeri RI, Direktorat Jenderal dan Konsuler: Laporan Perundingan Perjanjian Ekstradisi dan Perjanjian MLA, 24-25 Februari 2016, dalam Firdaus. (2017). Perjanjian
Convention against Transnational Organized Crime (UNCTOC) memandatkan bahwa kerja sama hukum antarnegara dalam masalah pidana harus berlandaskan pada beberapa prinsip hukum umum, antara lain:

a. Kecukupan bukti (sufficiency of evidence)

Demi keberhasilan dalam permintaan bantuan timbal balik dalam masalah pidana maka persiapan bukti-bukti yang mencukupi menjadi persyaratan utama membuat permintaan bantuan timbal balik dalam masalah pidana kepada negara lain. Besarnya jumlah bukti yang diperlukan ditentukan sebagian oleh ketentuan peraturan perundang-undangan di negara diminta dan sebagian lagi ditentukan oleh sifat permintaan yang diminta. Secara umum, semakin koersif sifat permintaan yang diminta maka semakin kompleks alat bukti yang diperlukan, misalnya permintaan untuk memperoleh informasi rekening bank atau aset seseorang yang berada di luar negeri. Persyaratan bukti-bukti yang diperlukan untuk mendapatkan jenis permintaan yang sama di negara yang berbeda akan sangat bervariasi tergantung pada persyaratan perjanjian yang dibentuk, peraturan domestik masing-masing negara dan sistem hukum dari negara-negara yang terlibat dalam proses permintaan bantuan timbal balik dalam masalah pidana tersebut. Dengan mencoba memahami hukum di negara diminta dan membangun komunikasi informal sebelum mengirimkan permintaan bantuan timbal balik dalam masalah pidana dengan ototritas pusat negara

Bantuan Timbal Balik Dalam Masalah Pidana Antara Republik Indonesia Dan Republik Islam Iran,Jurnal Penelitian Hukum De Jure, ISSN 1410-5632 Vol. 17 No. 4, h. 351 - 371 
diminta akan membantu negara peminta untuk memenuhi syaratsyarat yang diperlukan oleh negara diminta dalammenyampaikan permintaan bantuan timbal balik dalam masalah pidana kepada negara diminta ${ }^{7}$.

b. Kriminalitas ganda (dual criminality)

Kriminalitas ganda adalah prinsip hukum yang mengatur bahwa perbuatan seseorang, pada kasus yang menjadi subjek dari permintaan bantuan timbal balik dalam masalah pidana kepada negara lain dapat diterima sebagai suatu tindak kejahatan baik di negara peminta maupun di negara diminta. Konsep kriminalitas ganda merupakan konsep yang tampaknya lebih memiliki pengaruh besar dalam kerja sama yang terkait dengan bantuan timbal balik dalam masalah pidana, namun konsep tersebut juga dapat ditemukan dari waktu ke waktu pada ketentuan yang berkaitan dengan bantuan timbal balik dalam masalah pidana. Di sisi lain, kriminalitas ganda bisa saja tidak diperlukan sama sekali, atau diperlukan dalam permintaan bantuan timbal balik dalam masalah pidana dengan tujuan koersif tertentu atau diperlukan untuk segala jenis permintaan bantuan timbal balik dalam masalah pidana ${ }^{8}$.

Semua ketentuan tersebut akan tergantung pada aturan nasional dari negara yang menerima permintaan

${ }^{7}$ Manual on Mutual Legal Assistance and Extradition, United Nations Office On Drugs And Crime, New York, September 2012, hlm. 69. Di unduh di https://www.unodc.org / documents / organizedcrime/Publications/Mutual_Legal_Assis tance_Ebook_E.pdf

8 Prost, Kimberly. (2016). "Practical solutions to legal obstacles in mutual legal assistance", dalam Dennying Safe Heaven to the Corrupt and the Proceeds of Corruption, ADB/OECD Anti Corruption Initiative for Asia bantuan timbal balik dalam masalah pidana. Penyusun dokumen permintaan bantuan timbal balik dalam masalah pidana tersebut harus dapat memahami aturan nasional dari negara diminta pada saat menyusun rancangan permintaan bantuan timbal balikdalam masalah pidana. Hal tersebut menekankan bahwa uji kriminalitas ganda bersifat menentukan yaitu bahwa subjek permintaan bantuan timbal balik dalam masalah pidana tersebut merupakan suatu tindak pidana di kedua negara dan bukan dalam konteks perbuatan tersebut dapat dihukum sebagai tindak pidana yang sama di masing-masing negara.

Perspektif UNCTOC (Konvensi Palermo, 2000) Pasal 18 ayat 9 menempatkan isu kriminalitas ganda yang mengijinkan negara untuk menolak permintaan apabila syarat kriminalitas ganda tidak terpenuhi. Namun ketentuan pada pasal tersebut juga memberikan pilihan kepada negara untuk menghapus ketentuan tersebut jika tetap berkehendak memberikan bantuan dalam situasi apapun jika dipandang sesuai, terlepas dari apakah tindak pidana yang menjadi subjek dalam permintaan bantuan timbal balik dalam masalah pidana tersebut adalah suatu tindak pidana atau bukan suatu tindak pidana di negara diminta $^{9}$

Negara peminta harus melihat kemungkinan untuk menggunakan pilihan tersebut dengan negara

and the Pacific, Manila. h. 33. dalam Kementerian Hukum Dan Hak Asasi Manusia,(2016).Naskah Akademik Rancangan Undang-Undang Tentang Pengesahan Perjanjian Bantuan Timbal Balik Dalam Masalah Pidana Antara Republik Indonesia Dan Persatuan Emirat Arab (Treaty On Mutual Legal Assistance In Criminal Matters Between The Republic Of Indonesia And The United Arab Emirates)

${ }^{9}$ Manual on Mutual Legal Assistance and Extradition, Op.cit., 2012, hlm. 70. 
diminta yang mempunyai aturan hukum kriminalitas ganda dalam ketentuan peraturan bantuan timbal balik dalam masalah pidana di negaranya. Lebih lanjut dalam Pasal 46 ayat 9 huruf (b) UNCAC, disebutkan bahwa kriminalitas ganda diperlukan hanya dalam konteks permintaan bantuan timbal balik dalam masalah pidana yang memerlukantindakan-tindakan hukum yang bersifat memaksa (coercive measures) .

c. Resiprositas (reciprocity)

Kerja sama bantuan timbal balik dalam masalah pidana dapat dilakukan berdasarkan perjanjian antara negara negara yang berkepentingan. Namun demikian, apabila belum ada perjanjian, pelaksanaan kerja sama tersebut dapat dilakukan dengan berdasarkan pada prinsip resiprositas. Dengan prinsip ini, negara yang diminta pada dasarnya mendapatkan jaminan dari pihak peminta untuk diberikan bantuan yang sama apabila di kemudian hari diperlukan. Prinsip resiprositas ini merupakan prinsip yang diakui secara internasional dan melandasi kerja sama antar negara. Dalam berbagai perjanjian dan peraturan domestik di berbagai negara, prinsip resiprositas merupakan prinsip saling timbal balik baik yang bersifat menguntungkan dan memberi manfaat atau dalam bentuk retaliasi ${ }^{10}$. Atau hukuman yang diberikan oleh salah satu negara kepada warga negara atau badan hukum dari negara lain dan bersifat adil. Dalam konteks bantuan timbal balik dalam masalah pidana, prinsip resiprositas dapat dituangkan dalam perjanjian secara tertulis di mana negara yang berkepentingan harus menegaskan komitmennya masingmasing untuk memberikan jaminan bantuan yang serupa apabila di kemudian hari ada permintaanyang sama dari negara yang telah membantunya. Prinsip tersebut sangat berguna sebagai dasar kerja sama bagi negara-negara yang tidak mempunyai dasar perjanjian kerja sama atau belum memiliki hubungan perjanjian kerja sama di bidang bantuan timbal balik dalam masalah pidana atau diperlukan sebagai syarat aturan domestik masingmasing negara ${ }^{11}$.

Pasal 18 ayat 1 UNCTOC disebutkan bahwa:

"States Parties shall afford one another the widest measure of mutual legal assistance in investigations, prosecutions and judicial proceedings in relation to the offences covered by this convention as provided for in article 3 and shall reciprocally extend to one another similar assistance..."

Konvensi tersebut memberikan dasar bagi negara-negara untuk saling bekerja sama dalam penegakan hukum yang bersifat transnasional dan menjadi acuan bagi negara-negara yang tidak mempunyai hubungan kerja sama formal untuk dapat memberikan bantuan dengan dasar resiprositas.

d. Kekhususan (The rule of speciality/use limitation)

Penerapan prinsip ini dimaksudkan agar informasi atau alat bukti yang diminta oleh negara peminta tidak digunakan untuk proses investigasi, penuntutan atau proses hukum selain

terjemahkan/inggrisindonesial retaliation, (Diakses pada Tanggal 3 Maret 2017)
${ }_{11}$ Ibid pembalasan atau tindakan balasan. Diakses pada laman https://id.oxforddictionaries.com 
terhadap kasus yang dimintakan ${ }^{12}$. Bantuan yang diberikan oleh negara diminta kepada negara peminta sebagai jawaban dari permintaan yang diajukan, hanya dapat digunakan untuk tujuan yang disebutkan dalam dokumen permintaan yang diajukan oleh negara peminta.

e. Ne bis in idem (double jeopardy)

Prinsip $\mathrm{Ne}$ bis in idem terkadang menjadi persoalan ketika berhadapan dengan isu bantuan timbal balik dalam masalah pidana. Masing-masing negara mempunyai pendapat yang bermacam-macam terkait dengan prinsip ne bis in idem dalam perjanjian maupun dalam peraturan domestiknya. Berbagai definisi dari prinsip tersebut seringkali mempertimbangkan halhal berikut:

1) Apakah orang yang menjadi subjek permintaan bantuan timbal balik dalam masalah pidana tersebut telah menjalani hukumannya di negara diminta atau di negara peminta?

2) Apakah orang yang menjadi subjek permintaan bantuan timbal balik dalam masalah pidana tersebut telah menjalani hukumannya di negara ketiga?

3) Kadang-kadang pertanyaannya adalah bukan pada apakah orang tersebut telah dihukum, namun apakah orang tersebut telah diadili, dihukum, atau dibebaskan.

Undang-Undang Nomor 1 Tahun 2006 tentang Bantuan Timbal Balik dalam Masalah Pidana mengatur bahwa berdasarkan prinsip ne bis in idem bantuan tidak dapat diberikan jika kasus tersebut telah diputus dan memiliki kekuatan hukum yang tetap, sehingga seseorang tidak dapat dituntut atau dihukum untuk kedua kalinya dalam perkara yang sama. Prinsip ne bis in idem tersebut juga berlaku dalam perjanjian bantuan timbal balik dalam masalah pidana regional ASEAN Mutual Legal Assistance (MLA) Treaty Pasal 3 ayat (1) huruf (d) dan bersifat wajib (mandatory) dalam penerapannya.

Penerapan Sistem Bantuan Timbal Balik dalam Masalah Pidana (Mutual Legal Assistance) diwujudkan dalam implementasi terhadap Undang-Undang Nomor 1 Tahun 2006 tentang Bantuan Timbal Balik dalam Masalah Pidana, yaitu dengan menjalin kerjasama dengan negara yang memiliki potensi untuk dijadikan sebagai tempat bersembunyi maupu menyimpan aset hasil kejahatan tersebut. Hal ini adalah bentuk keseriusan pemerintah Indonesia dalam upaya penanggulangan kejahatan transnasional

\section{Upaya pencegahan Cyber Crime Lintas Yurisdiksi dengan penerapan Sistem Bantuan Timbal Balik dalam Masalah Pidana (Mutual Legal Assistance)}

Negara Republik Indonesia adalah negara hukum berdasarkan Pancasila dan Undang-Undang Dasar Negara Republik Indonesia Tahun 1945 yang mendukung dan menjamin kepastian, ketertiban, dan perlindungan hukum yang berintikan keadilan dan kebenaran.tindak pidana terutama yang bersifat transnasional atau lintas negara mengakibatkan timbulnya permasalahan hukum suatu negara dengan negara lain yang memerlukan penanganan melalui hubungan baik berdasarkan hukum di masing-masing negara. Terlebih lagi Indonesia yang wilayahnya terletak di persimpangan lalu lintas internasional, merupakan destinasi potensial bagi para pelaku kejahatan seperti penyeludupan,

${ }^{12}$ Ibid, h. 18 
perdagangan gelap manusia dan tenaga kerja, terorisme dan lainnya.

Undang-Undang ini bertujuan memberikan dasar hukum bagi Pemerintah Republik Indonesia dalam meminta dan/atau memberikan bantuan timbal balik dalam masalah pidana dan pedoman dalam membuat perjanjian bantuan timbal balik dalam masalah pidana dengan negara asing, dalam dua dokumken konferensi PBB mengenai The Prevention of Crime and The Treatment of Offenders di Havana, Cuba pada tahun 1990, dan di Wina, Austria pada tahun 2000, ada dua istilah yangg dikenal yaitu : "cybercrime", dan "computer related crime". Dalam bac ground paper untuk lokakarya konfrensi PBB X/2000 di Wina, Austria, istilah cybercrime dibagi dalam dua kategori, yaitu pertama, cybercrime dalam arti sempit disebut computer crime, kedua cybercrime dalam arti luas disebut computer related crime.

Dokumen tersebut dinyatakan ${ }^{13}$ :

a) Cybercrime in narrow sanse (computer crime): any legal behaviour directed by means of elctronik operations that targets the security of computer system and data procssed by them.

b) Cybercime in a broader sense (computer related crime): any ilegal behaviour commited by means on in reltion to, a computer systemor network, including such crime as illegal possesion, offering or distribution by meaans of a computer system or network.

Dengan demikian cybercrime meliputi kejahatan, yaitu yang dilakukan :

a) Dengan menggunakan saranasarana dari sistem atau jaringan komputer (by means of a computer system or network);

13 Tianotak, Nazarudin. (2011). Urgensi Cyberlaw Di Indonesia Dalam Rangka Penangan Cybercrime Disektor Perbankan. Jurnal Sasi Vol. 17 No. 4 Bulan Oktober - Desember, h. 20-27 b) Didalam sistem atau jaringan komputer (in a computer system or network) dan

c) Terhadap sistem atau jaringan komputer (ageinst a computer system or network).

Namun Selama ini produk kebijakan legislasi sering menampilkan sanksi tindakan yang terkesan ragu-ragu dan tersembunyi, artinya pandangan para pemegang kebijakan legislasi masih berpaham tradisional-klasik yang hanya merujuk pada konsep KUHP dan menganggap sanksi tidakan tidak lebih sebagai suatu 'sanksi perawatan'. Pandangan demikian akan menghambat penanggulangan kejahatan berdimensi baru (new dimension of criminality) khususnya dilakukan oleh korporasi sebagai subyek hukum pidana karena karakteristiknya kejahatan tersebut lebih membutuhkan jenis sanksi yang tidak bersifat retributive belaka ${ }^{14}$.

Penerapan hukum pidana di Indonesia, berlaku asas teritorial sebagaimana diatur dalam Pasal 2 KUHP yaitu bahwa "aturan pidana dalam perundang-undangan Indonesia diterapkan bagi setiap orang yang melakukan suatu tindak pidana di Indonesia" dan perluasan dari asas teritorial ini diatur dalam Pasal 3 KUHP yang menyatakan, bahwa "ketentuan pidana perundang-undangan Indonesia berlaku bagi setiap orang yang di luar wilayah Indonesia melakukan tindak pidana didalan kendaraan air atau pesawat udara Indonesia”. Tujuannya adalah agar perbuatan pidana yang terjadi di dalam kapal atau pesawat terbang yang berada di perairan bebas atau berada di wilayah udara bebas, tidak termasuk wilayah territorial suatu negara, sehingga tidak ada yang mengadili apabila terjadi suatu

${ }^{14}$ Leasa, E. Z. (2010). Penerapan Sanksi Pidana Sanksi Tindakan (Double Track System) Dalam Kebijakan Legislasi. Jurnal Sasi Vol. 16 No. 4 Bulan Oktober - Desember, h. 52 
perbuatan pidana. Namun demikian, berlakunya asas teritorial berdasarkan KUHP tersebut juga dibatasi pemberlakuan ketentuan hukum internasional yang telah diakui oleh pemerintah Indonesia sesuai dengan ketentuan Pasal 9 KUHP.

Mencegah dan memberantas tindak pidana pencucian uang, maka berdasarkan Pasal 44 Negara Republik Indonesia dapat melakukan kerja sama bantuan timbal balik di bidang hukum dengan negara lain baik melalui forum bilateral maupun multilateral ataupun berdasarkan prinsip resiprositas. Kerja sama tersebut meliputi :

a) pengambilan barang bukti dan pernyataan seseorang, termasuk pelaksanaan surat rogator;

b) pemberian barang bukti berupa dokumen dan catatan lain;

c) identifikasi dan lokasi keberadaan seseorang;

d) pelaksanaan permintaan untuk pencarian barang bukti dan penyitaan;

e) upaya untuk melakukan pencarian, pembekuan, dan penyitaan hasil kejahatan;

f) mengusahakan persetujuan orangorang yang bersedia memberikan kesaksian atau membantu penyidikan di negara peminta;

g) bantuan lain yang sesuai dengan tujuan pemberian kerja sama timbal balik yang tidak bertentangan dengan peraturan perundangundangan.

Melakukan kerja sama bantuan timbal balik, pejabat yang berwenang dapat diminta untuk melakukan tindakan kepolisian berupa :

a) penggeladahan

b) pemblokiran

c) penyitaan

d) pemeriksaan surat

e) pengambilan keterangan atau hal lain sesuai dengan ketentuan yang diatur dalam hukum acara pidana maupun undang-undang tindak pidana pencucian uang Barang bukti, pernyataan, dokumen atau catatan lain yang merupakan alat bukti yang diperoleh dari kerja sama pemberian bantuan timbal balik dalam masalah pidana merupakan alat bukti yang dipergunakan dalam pemeriksaan tindak pidana pencucian uang sesuai dengan peraturan perundang-undangan.

Kerja sama tentang bantuan timbal balik dalam masalah pidana merupakan upaya memudahkan penanganan proses penyidikan, penuntutan, dan pemeriksaan di sidang pengadilan atas suatu masalah pidana yang timbul baik di pihak peminta maupun pihak diminta. Kerja sama dimaksud dapat dilakukan dengan perjanjian maupun atas dasar hubungan baik tanpa mengenyampingkan hukum nasional negara masing-masing.

Undang-Undang Nomor 1 Tahun 2006 tentang Bantuan Timbal Balik dalam Masalah Pidana merupakan dasar hukum serta pedoman bagi Republik Indonesia untuk membuat kerja sama mengenai bantuan timbal balik dalam masalah pidana dengan negara lain. Berdasarkan Pasal 2 Undang-Undang Nomor 1 Tahun 2006 tentang Bantuan Timbal Balik dalam Masalah Pidana, bahwa Kerja sama mengenai bantuan timbal balik yang dilakukan berkenaan dengan pelaksanaan kegiatan penyidikan, penuntutan, dan pemeriksaan di sidang pengadilan yang meliput :

a) mengidentifikasi dan mencari orang;

b) mendapatkan pernyataan atau bentuk lainnya;

c) menunjukkan dokumen atau bentuk lainnya;

d) mengupayakan kehadiran orang untuk memberikan

e) keterangan atau membantu penyidikan;

f) menyampaikan surat;

g) melaksanakan permintaan penggeledahan dan penyitaan; 
h) memperoleh kembali sanksi denda berupa uang sehubungan dengan tindak pidana;

i) melarang transaksi kekayaan, membekukan aset yang dapat dilepaskan atau disita, atau yang mungkin diperlukan untuk memenuhi sanksi denda yang dikenakan, sehubungan dengan tindak pidana;

j) mencari kekayaan yang dapat dilepaskan, atau yang mungkin diperlukan untuk memenuhi sanksi denda yang dikenakan, sehubungan dengan tindak pidana; dan/atau

k) bantuan lain termasuk termasuk tukar menukar informasi yang berkenaan dengan pembuktian Pengesahan Perjanjian Bantuan Timbal Balik telah sesuai dengan pengaturan tersebut.

Undang-Undang Nomor 1 Tahun 2006 tentang Bantuan Timbal Balik dalam Masalah Pidana memberikan dasar hukum bagi Republik Indonesia untuk meminta maupun memberikan bantuan timbal balik dalam masalah pidana melalui kerja sama dengan negara lain. Perjanjian yang dibuat oleh Pemerintah Republik Indonesia dengan negara lain, termasuk dengan PEA didasarkan pada Pasal 11 UUD NRI Tahun 1945 dan ketentuan lebih lanjut mengenai hal tersebut diatur dalam Undang- Undang Nomor 24 tahun 2000 tentang Perjanjian Internasional Merujuk pada UndangUndang Nomor 24 Tahun 2010 tentang Perjanjian Internasional, Pasal 9 mengatur bahwa pengesahan perjanjian internasional oleh Pemerintah Republik Indonesia dilakukan sepanjang dipersyaratkan oleh perjanjian internasional tersebut. Selanjutnya, dalam Pasal 10 Undang- Undang Nomor 24 Tahun 2010 tentang Perjanjian Internasional disebutkan bahwa pengesahan terhadap suatu perjanjian internasional yang dilakukan dengan undangundang apabila salah satunya berkenaan dengan masalah kedaulatan, hak asasi manusia, dan keamanan negara.

Indonesia sebagai bagian dari masyarakat dunia turut serta dalam pergaulan internasional dengan menjalin kerja sama baik secara bilateral maupun multilateral dengan tetap mengedepankan tujuan negara yaitu melindungi segenap bangsa Indonesia dan seluruh tumpah darah Indonesia, ikut melaksanakan ketertiban dunia yang berdasarkan kemerdekaan, perdamaian abadi, dan keadilan sosial, yang pada akhirnya turut serta dalam mewujudkan tatanan dunia baru yang memberikan manfaat kesejahteraan dan perdamaian bagi masyarakat dunia. Namun perkembangan teknologi informasi dan transportasi secara global menimbulkan masalah yang sangat kompleks termasuk berkembangnya tindak pidana yang tidak lagi mengenal yurisdiksi, yang penangannya harus dilakukan melalui kerja sama dengan negara yang potensial dijadikan tempat persembunyian maupun penyimpanan aset dari tindak pidaa khususnya pencucian uang. Hal ini menjadi salah satu upaya pencegahan cyber crime lintas yurisdiksi dengan penerapan Sistem Bantuan Timbal Balik dalam Masalah Pidana (Mutual Legal Assistance)

\section{P E N U T U P}

Penerapan Sistem Bantuan Timbal Balik dalam Masalah Pidana (Mutual Legal Assistance) diwujudkan dalam implementasi terhadap Undang-Undang Nomor 1 Tahun 2006 tentang Bantuan Timbal Balik dalam Masalah Pidana, yaitu dengan menjalin kerjasama dengan negara yang memiliki potensi untuk dijadikan sebagai tempat bersembunyi maupu menyimpan aset hasil kejahatan tersebut. perkembangan teknologi informasi dan transportasi secara global menimbulkan masalah yang sangat kompleks termasuk berkembangnya tindak pidana yang tidak lagi mengenal yurisdiksi, yang penangannya harus dilakukan melalui 
kerja sama dengan negara yang potensial dijadikan tempat persembunyian maupun penyimpanan aset dari tindak pidaa khususnya pencucian uang. Hal ini menjadi salah satu upaya pencegahan cyber crime lintas yurisdiksi dengan penerapan Sistem Bantuan Timbal Balik dalam Masalah Pidana (Mutual Legal Assistance)

\section{DAFTAR PUSTAKA}

Sutarman. (2007). Cyber Crime-Modus Operandi dan Penanggulangannya. Jogjakarta: Laksbang Pressindo.

Syahdeini, Sutan Remy. (2009). Kejahatan \& Tindak Pidana Komputer. Jakarta: Pustaka Utama Grafiti.

\section{Lain-Lain}

Direktorat Perjanjian Internasional Politik dan Keamanan Wilayah Kementerian Luar Negeri Republik Indonesia (2010). Pointers Upaya Pemerintah RI dalam Pengembalian Aset (Asset Recovery) Hasil Tindak Pidana di Luar Negeri.

Leasa, E. Z. (2010). Penerapan Sanksi Pidana Sanksi Tindakan (Double Track System) Dalam Kebijakan Legislasi. Jurnal Sasi Vol. 16 No. 4 Bulan Oktober - Desember.

Kementerian Luar Negeri RI, DirektoratJenderal dan Konsuler: Laporan Perundingan Perjanjian Ekstradisi dan Perjanjian MLA, 2425 Februari 2016, dalam Firdaus. (2017). Perjanjian Bantuan Timbal Balik Dalam Masalah Pidana Antara Republik Indonesia Dan Republik Islam Iran,Jurnal Penelitian Hukum De Jure, ISSN 1410-5632 Vol. 17 No. 4 , Desember 2017:p. 351 - 371
Prost, Kimberly. (2016). "Practical solutions to legal obstacles in mutual legal assistance", dalam Dennying Safe Heaven to the Corrupt and the Proceeds of Corruption, ADB/OECD Anti Corruption Initiative for Asia and the Pacific, Manila. hlm. 33. dalam Kementerian Hukum Dan Hak Asasi ManusiaNaskah Akademik Rancangan Undang-Undang Tentang Pengesahan Perjanjian Bantuan Timbal Balik Dalam Masalah Pidana Antara Republik Indonesia Dan Persatuan Emirat Arab (Treaty On Mutual Legal Assistance In Criminal Matters Between The Republic Of Indonesia And The United Arab Emirates.

Tianotak, Nazarudin (2011). Urgensi Cyberlaw Di Indonesia, Jurnal Sasi Vol. 17 No. 4 Bulan Oktober Desember.

Marfuatul Latifah. (2016). Penunjukan Otoritas Pusat Dalam Bantuan Timbal Balik Pidana Di Indonesia. Jurnal Negara Hukum: Vol. 7, No. 1, Juni 2016. P.51-69

Manual on Mutual Legal Assistance and Extradition, United Nations Office On Drugs And Crime, New York, September 2012. https://www.unodc.org/documents/ organizedcrime/Publications/Mutua 1_Legal_Assistance_Ebook_E.pdf

Retaliasi dapat diartikan sebagai pembalasan atau tindakan balasan. Diakses pada laman https://id.oxforddictionaries.com/ter jemahkan/inggrisindonesia/ 